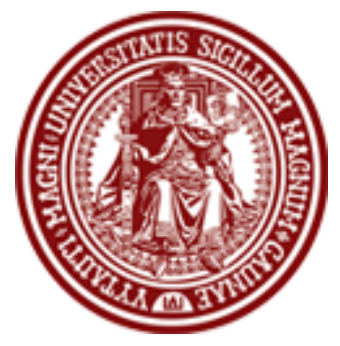

BALTIC JOURNAL OF LAW \& POLITICS

VOLUME 2, NUMBER 2 (2009)

ISSN 2029-0405

http://www.versita.com/science/law/bjlp

Cit.: Baltic Journal of Law \& Politics 2:2 (2009): 165-180

DOI: $10.2478 / \mathrm{v} 10076-009-0015-7$

\title{
LOCALIZING GLOBAL POLITICAL MATTERS THROUGH NEW MEDIA: SOME REFLECTIONS ON COMMUNICATION CULTURE
}

\author{
Auksè Balčytienè \\ Professor; Dr \\ Vytautas Magnus University Faculty of Political Science and Diplomacy \\ (Lithuania) \\ Contact information \\ Address: K. Donelaičio str. 58, LT-44248 Kaunas, Lithuania \\ Phone: (+370) 37228696 \\ E-mail address: a.balcytiene@pmdf.vdu.It

\section{Lina Auškalnienè} \\ Doctoral Candidate \\ Vytautas Magnus University Faculty of Political Science and Diplomacy \\ (Lithuania) \\ Contact information \\ Address: K. Donelaičio str. 58, LT-44248 Kaunas, Lithuania \\ Phone: (+370) 37327868 \\ E-mail address: I.auskalniene@pmdf.vdu.It
}

\section{Inesa Birbilaitè}

Doctoral Candidate

Vytautas Magnus University Faculty of Political Science and Diplomacy (Lithuania)

Contact information

Address: K. Donelaičio str. 58, LT-44248 Kaunas, Lithuania

Phone: $(+370) 37327868$

E-mail address: i.birbilaite@pmdf.vdu.It

\section{Aušra Vinciūnienè}

Doctoral Candidate

Vytautas Magnus University Faculty of Political Science and Diplomacy (Lithuania)

Contact information

Address: K. Donelaičio str. 58, LT-44248 Kaunas, Lithuania

Phone: (+370) 37327868

E-mail address: a.vinciuniene@vks.vdu.It 
Received: December 29, 2009; reviews: 2; accepted: January 21, 2010.

\section{ABSTRACT}

This paper seeks to reassess the potential of new media in transnational political communication. It questions whether a wide availability of online news sources offering diverse views could become useful means in overcoming national (cultural and geographic) barriers in reporting about global political matters.

The discussion here moves on several levels of analysis. First, it draws attention to the impact of the Internet on political communication. By relying on results obtained from research studies in international (European) news communication, it also stresses the significance of contextual factors (local political, economic and cultural conditions) in transnational political communication. The paper proposes that the Internet and social media applications (blogs, social forums) may help journalists as well as citizens to retrieve background information on complex issues of global character. Simultaneously, such online communication where common interests of citizens are recognized and addressed in less formal manner may help different audiences to develop a sense of transnational understanding which could enrich news and views communicated. On the other hand, this paper also stresses that there is no universal culture of communication; instead, all characteristics of communication are related to different political, economic, social and cultural conditions where these traditions, values and norms have developed and are sustained.

The paper concludes that the communication of global political matters involves two conflicting paradigms of globalization and localism. Both of these paradigms must be adequately addressed in the analysis of the role and functions of the Internet in communication of global political matters to local audiences.

\section{KEYWORDS}

Political communication, new media, communication culture, European politics, globalization, localism 


\section{INTRODUCTION}

In recent years the debate on how new information and communication technologies affect the nature and traditions of political communication in modern democracies has generated considerable attention among political scientists. In spite of diverse drawbacks predicted in online political communication practices, one thing is clear - the Internet has the potential to serve as a space where political information can be shared and issues discussed, and where those interested can engage in political deliberation. Moreover, more so than ever before, new media applications offer more channels, chances and incentives to tailor political communication to particular identities, conditions and tastes.

However, general figures of media- and Internet-use show that the mainstream media still plays the most important role in communication in day-today political affairs. The coverage of local and international issues in mass media, however, lacks balance. In European affairs reporting, for example, different studies performed on a cross-national level demonstrate that in spite of the growing importance of EU politics there is still a lack of analytical reporting on European issues in mainstream media Europe-wide. ${ }^{1}$ The mainstream national media is very locally oriented and its agenda is primarily focused on issues of local relevance. As popularly conceived, there is no universal culture of journalism and communication. A variety of communication cultures exist which can be compared and contrasted according to certain comparative criteria such as histories and traditions of communications development, professional procedures of news gathering and distribution, and so forth. This suggests that most media (as well as political) systems are still considered to be national media systems with diverse experiences of rapid commercialization, marketization, de-regulation, digitalization, regional integration, Europeanization, globalization and so forth.

Clearly, in modern democracies the public life is local and global at the same time. For example, in European communication and politics, as a result of intensive transnationalization and regional integration a new kind of (trans-border, transnational) communication emerged which requires from different citizen groups reorientation from predominantly local and national interests to more global and

\footnotetext{
${ }^{1}$ Hans-Jörg Trenz, "Media Coverage on European Governance: Exploring the European Public Sphere in National Quality Newspapers," European Journal of Communication Vol. 19, No. 3 (2004); Christoph O. Meyer, "The Europeanization of Media Discourse: A Study of Quality Press Coverage of Economic Policy Co-ordination since Amsterdam," Journal of Common Market Studies Vol. 43, Issue 1 (2005); Marcel Machill, Marcus Beiler, and Corinna Fischer, "Europe-topics in Europe's Media. The Debate about the European Public Sphere: A Meta-Analysis of Media Content Analyses," European Journal of Communication Vol. 21, No. 1 (2006); Michael Brüggemann and Katharina Kleinen-von Königslöw, "Let's talk about Europe. Why Europeanization Shows a Different Face in Different Newspapers," European Journal of Communication Vol. 24, No. 1 (2009).
} 
international concerns. In addition, certain problem areas (environmental issues, health safety, regulation of financial matter, fraud and corruption, assuring security, fighting terrorism, etc.) require an understanding which involves a socalled transnational view on contradictory issues. Without reconsidering its global affairs reporting strategies and routines, the mainstream media are losing their positions as the prime channel of information for a variety of social actor groups (politicians, journalists, businessmen, public intellectuals, NGO leaders, etc.) who want to express their interests and discuss their concerns in an international arena. $^{2}$

In this context, it can be assumed that the Internet as well as other interactive social media applications could become useful means for people from different cultural backgrounds and traditions to engage, interact and form new kinds of transnational and intercultural public spaces. Communicators, too, will be forced to change their habits and learn new things and make adequate use of new media resources while reporting on issues of global concern - instead of being news gatherers they must become interpreters and evaluators of what is both credible and valuable.

\section{TECHNOLOGICAL CHALLENGES AND THEIR IMPACT ON POLITICAL COMMUNICATION}

Communication of issues of a global and transnational political character to local audiences raises different concerns. To a large extent, this type of communication involves two contradictory tendencies: globalization and localism. Both tendencies are simultaneously experienced by people living in many countries around the world. As citizens of one particular nation we are continuously affected by changes and challenges of a more global nature, especially by those which directly affect our economic and social well-being such as health or environmental conditions. $^{3}$ At the same time, to adequately understand and experience the consequences of all these challenges on local political, economic and cultural realms, we need mass media to provide a national frame of reference to those key issues.

Contemporary societies and their political communication systems are facing yet another challenge. Media has always contributed to political discourse. However, with the advent of new information and communication technologies

\footnotetext{
2 Manuel Castells, "The New Public Sphere: Global Civil Society, Communication Networks, and Global Governance," American Academy of Political \& Social Science Annals Vol. 616, No. 3 (2008).

3 Jason Corburn, Street Science: Community Knowledge and Environmental Health Justine (Cambridge: The MIT Press, 2005); Ulrika Olausson, "Global Warming global responsibility? Media frames of collective action and scientific certainty," Public Understanding of Science Vol. 18, No. 4 (2009).
} 
some prospects and potentials of new media in political communication are revealed and have to be reconsidered. As popularly conceived, the public trust, knowledge and understanding of political affairs are losing ground in many representative democracies, ${ }^{4}$ whereas the mainstream media apply different strategies of integrating user-generated content into its applications to engage decentralized grassroots communication forms into its content. ${ }^{5}$ In spite of imagined drawbacks, the emergence of new media applications and changes in communication associated with increasing connectivity between previously scattered audience groups bring apparent challenges into the political public sphere. Individual and collective forms of action transform the existing public sphere by its potential to increase deliberation, address public concerns on the transparency, diversity and accountability issues. Aside to contributing to the emergence of virtual public spaces of networked character, new media applications challenge the role and functions of both political and media actors. Interactive technologies offer new and alternative ways and channels (institutional websites, online press services, blogs, online political advertising, etc.) for politicians to reach their voters without the help of conventional mass media. Citizens, too, are better equipped (they have better competences, experience and knowledge) to access and assess news on the Internet, and thereby overstep borders of the official political communication sphere (Figure 1 ). ${ }^{6}$

\footnotetext{
4 Peter Dahlgren, "Doing Citizenship: The Cultural Origins of Civic Agency in the Public Sphere," European Journal of Cultural Studies Vol. 9, No. 3 (2006).

${ }^{5}$ Renita Coleman, Paul Lieber, Andew L. Mendelson, and David D. Kurpius, "Public Life and the Internet: If You Build a Better Website, Will Citizens Become Engaged?" New Media \& Society Vol. 10, No. 2 (2008).

${ }^{6}$ Erik Oddvar Eriksen, "An Emerging European Public Sphere," European Journal of Social Theory Vol. 8, No. 3 (2005).
} 


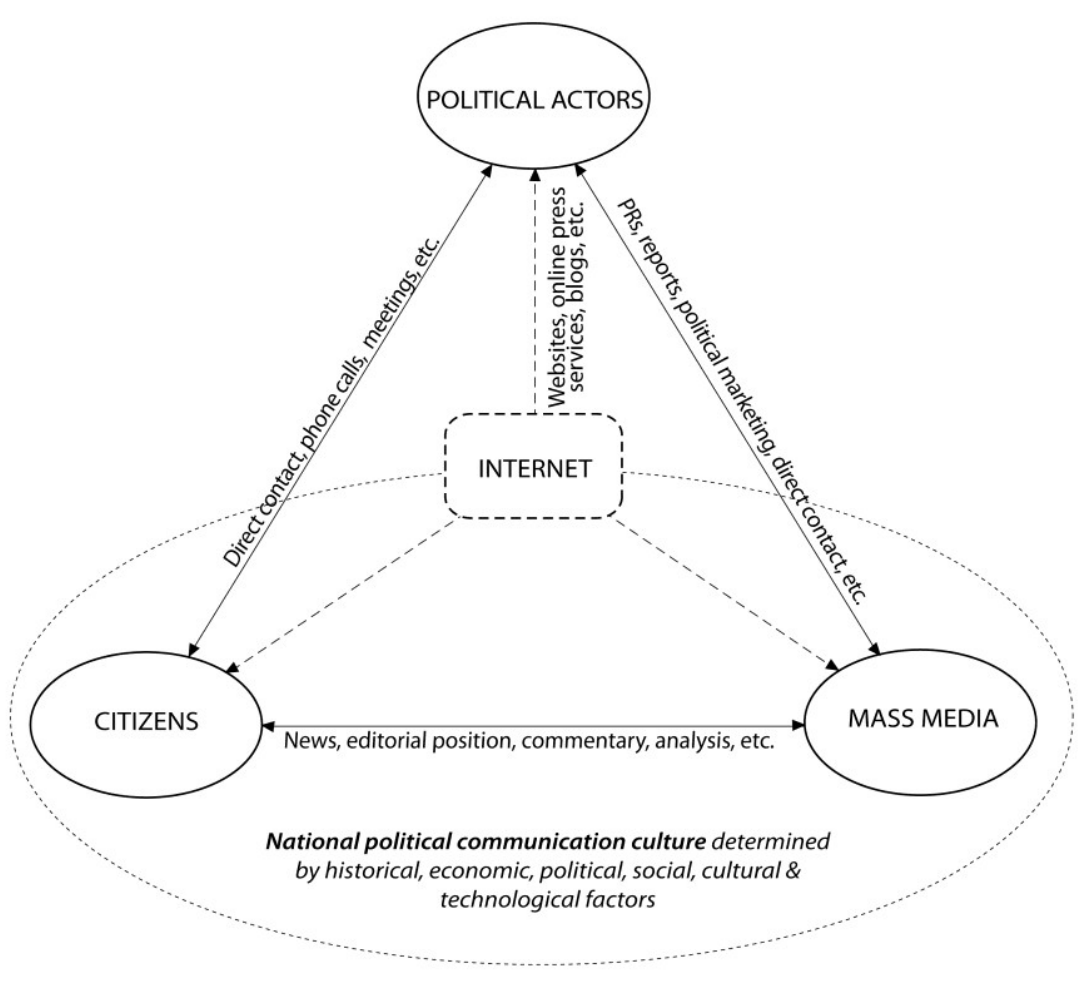

Fig. 1. Processes and actors in contemporary political communication ${ }^{7}$

Clearly, the twenty-first century's communication operates in a more integrated media culture where "new, digital technologies of mediation make possible more indirect techniques of representation which do not transcend the necessity for representing or being represented in a political democracy, but serve to democratize representation by making it a more direct relationship". ${ }^{8}$ Consequently, the most obvious outcome of all these changes in political and media fields is the reconfiguration of communication landscapes: "as citizens gain access to inexpensive communication technologies through which they can interact with the media, generate their own content and create alternative networks of information dissemination, the gate-keeping monopoly once enjoyed by editors and broadcasters is waning". ${ }^{9}$ Briefly, the Internet has indeed shifted the political communication to a much more personalized one, and politicians are forced to address more channels, to compete for the attention of a more fragmented audience and to target their messages to more fragmented groups than ever

\footnotetext{
7 Auksè Balčytienè and Aušra Vinciūnienè, "Political communication culture with a European touch: a view from Brussels," Sociologija: mintis ir veiksmas Vol. 3 (2008): 73.

${ }^{8}$ Stephen Coleman, "New Mediation and Direct Representation: Reconceptualizing Representation in the Digital Age," New Media and Society 7(2) (2005): 178.

${ }^{9}$ Michael Gurevitz, Stephen Coleman, and Jay G. Blumler, "Political Communication - Old and New Media Relationships," The ANNALS of the American Academy of Political and Social Science 625 (September 2009): 167.
} 
before. ${ }^{10}$ However, with the advent of new information and communication technologies the possibilities to facilitate new ways of public political participation have grown enormously. Sometimes the new media is even called the Fifth Estate, since it has several key distinctive and important characteristics: the ability to support institutions and individuals to enhance their 'communicative power' with opportunities to network within and beyond various institutional arenas; the provision of capabilities that enable the creation of networks of individuals which have a public, social benefit (e.g. through social networking Web sites). ${ }^{11}$ New media are not just useful tools for citizens or journalists; they are also very powerful actors.

Nevertheless, some scholars claim that "politics, for those already engaged or interested, is becoming denser, wider, and possibly more pluralistic and inclusive. At the same time the mass of unengaged citizens is becoming subject to greater communicative exclusion and experiencing increasing disengagement." ${ }^{12}$ Taking the optimistic point of view, the new media can become a new means and offer opportunities to serve as alternative sources of information. Journalists and bloggers argue that the Internet has increased the available space and possible choice of subject matter for publishing political news, since the new media is not necessary replacing journalism. Furthermore, new media is creating an important extra layer of information and diverse opinion. ${ }^{13}$ Current practices support this idea, as institutional actors understand the growing importance and usability of new media technologies and invest their communicational activities to conquer audiences online.

Generally, innovations in web development, computing technology, the proliferation of broadband and new forms of media contribute to the emergence of new media and their applicability in situations not seen or previously experienced. New media applications possess certain characteristics - richness of issues, its socially oriented nature as well as its global reach - which can be used to represent the formerly underrepresented alternative viewpoints, to be more inclusive, to offer critical insights into transnational debates and deliberations.

10 Peter Dahlgren, "Internet, Public Spheres and Political Communication: Dispersion and Deliberation," Political Communication Vol. 22, No. 2 (2005).

${ }_{11}$ William H. Dutton, "The Fifth Estate: Democratic Social Accountability through the Emerging Network of Networks," June 10, 2008 // http://papers.ssrn.com/sol3/papers.cfm?abstract_id=1167502 (accessed December 21, 2009).

12 Aeron Davis, "New Media and Fat Democracy: the Paradox of Online Participation," New Media and Society Vol. 11, No. 8 (2009): 2.

13 Nic Newman, "The Rise of Social Media and Its Impact on Mainstream Journalism: A study of how newspapers and broadcasters in the UK and US are responding to a wave of participatory social media, and a historic shift in control towards individual consumers, Working Paper," September 2009 // http://go2. wordpress.com/?id=725X1342\&site=reinventingthenewsroom. wordpress. com\&url=http $\% 3 \mathrm{~A}$ $\% 2 \mathrm{~F} \% 2$ Freutersinstitute.politics.ox.ac.uk\%2Ffileadmin $\% 2$ Fdocuments $\% 2$ FPublications $\% 2 \mathrm{FThe}$ rise_of_s ocial_media_and_its_impact_on_mainstream_journalism.pdf (accessed December 21, 2009); Aeron Davis, supra note 12 . 


\section{GLOBAL ISSUES AND LOCAL CULTURES}

Although they are autonomous fields, both politics and media are strongly affected by contextual factors such as local histories and traditions of publishing and communication, values and norms practiced by communicating actors. Simultaneously, contemporary politics and media are affected by other factors of a more global character, such as changes in media business models towards more commercialized and popularized production of content, as well as the emergence of strategic communications management in politics as well as technological convergence. Market-led reforms in both media and politics (such as commercialization of routines and messages communicated to fragmented audiences) affect the behavior of political actors, reproduction of political messages by the media, and eventually have an impact on how citizens consume the content and how they cope with the vast availability of information genres, formats and channels. As most recent developments in the political landscapes in developed countries make manifest, the new era of political communication is quickly emerging. Successful politics becomes impossible without strategic planning, careful selection of communication channels and control of messages communicated, and adequate management of political information.

With globalization, regional integration (Europeanization), intensive technological diffusion and informatization as well as gradual transnationalization of national political and communication spaces, the overall effects of globalization on local communication cultures remain of no less importance. Popularly conceived, communication practices are context bound. Communication is affected by certain social determinants such as political, economic and cultural factors which influence communication practices and messages, and produce considerable variations among journalism's professional models in different countries. In other words, what political news is selected and how news is framed by journalists, and what strategies of communication political parties choose (or do not choose) to communicate with their audiences very much depend on contextual features such as histories, traditions and norms of national communication cultures. ${ }^{14}$ At the same time, apart from the inherent complexity of all these local processes, different communication cultures can be compared and contrasted according to certain comparative criteria such as histories and traditions of journalism development and

\footnotetext{
${ }^{14}$ Frank Esser and Barbara Pfetsch, Comparing Political Communication. Theories, Cases and Challenges (Cambridge: Cambridge University Press, 2004); Daniel Hallin and Paolo Mancini, Comparing Media Systems. Three Models of Media and Politics (Cambridge: Cambridge University Press 2004); Paolo Mancini, "Journalism Cultures: A Multi-level Proposal"; in: Oliver Hahn and Roland Schroeder, eds., Journalistische Kulturen: Internationale und interdisziplinare Theoriesbausteine (Koln: Herbert von Halem Verlag, 2008).
} 
book publishing, professional procedures of news gathering, editing and distribution, communication with political news sources, and so forth. ${ }^{15}$

In this context, the communication of matters of a global and transnational character (such as European political news or news about health safety or environmental risks as well as other global threats) to local audiences appears to be an interesting research case. A number of studies, for example, disclose that the way journalists from different European countries interact with transnational EU political institutions is dependent on practicalities (learned communication practices and traditions) in national settings. ${ }^{16}$ This kind of national communication culture becomes even more apparent when EU reporting practices of foreign correspondents are studied in an international setting in Brussels: ${ }^{17}$ it appears that the highest probability for the transnational EU news to enter the national agenda is to nationalize (i.e. 'to domesticate') European issues by giving them a national reference. However, in their attempts to domesticate and localize issues of a global character to be understood locally, journalists encounter different problems. As becomes clear, the character of the national coverage of global issues is largely dependent on local politico-economic preconditions for particular journalism cultures. ${ }^{18}$ Although working in a transnational context in Brussels and specializing in foreign and European news reporting, all foreign correspondents remain national journalists working for domestic media organizations operating in different political, economic and cultural conditions. Solving the conflicts between what is happening 'here' (in Brussels) and what is expected 'there' (in the home country) is a central aspect of an EU correspondent's job and, thus, of EU news production logics.

\footnotetext{
${ }^{15}$ Daniel Hallin and Paolo Mancini, supra note 14.

16 Silke Adam, "Domestic Adaptations of Europe: A Comparative Study of the Debates on EU Enlargement and a Common Constitution in the German and French Quality Press," International Journal of Public Opinion Research Vol. 19, No. 4 (2007); Paul Statham, "Making Europe News: How Journalists View Their Role and Media Performance," Journalism Vol. 9, No. 4 (2008); Holli. A. Semetko, Claes de Vreese, Jochen Peter, "Europeanised Politics - Europeanised Media? European Integration and Political Communication," West European Politics Vol. 23, No. 4 (2000); Heikki Heikkila and Risto Kunelius, "Journalists imagining the European Public Sphere," Javnost: The Public Vol. 14, No. 4 (2007); Ruud Koopmans, "Who inhabits the European public sphere? Winners and losers, supporters and opponents in Europeanised public debates," European Journal of Political Research Vol. 46, No. 2 (2007); Vanni Tjernström, "Nordic Newspapers on the EU: European Political Journalism after 'Non' and 'Nee'," Journalism 9(4) (2008); Barbara Pfetsch, Silke Adam, and Barbara Eschner, "The Contribution of the Press to Europeanization of Public Debates: A Comparative Study of Issue Salience and Conflict Lines of European Integration," Journalism Vol. 9, No. 4 (2008).

17 David Morgan, "British Media and European Union News: The Brussels News Beat and its Problems," European Journal of Communication Vol. 10, No. 3 (1995); Olivier Baisnée, "Can political journalism exist on EU level?"; in: R. Kuhn and E. Neveu, eds., Political Journalism: New Challenges, New Practices (London/New York: Routledge, 2002); Neil T. Gavin, "British Journalists in the Spotlight: Europe and Media Research," Journalism Vol. 2, No. 3 (2001); Sophie Lecheler, "EU Membership and the Press: An Analysis of the Brussels Correspondents from the New Member States," Journalism Vol. 9, No. 4 (2008). 18 AIM Research Consortium, ed., Understanding the Logic of EU Reporting from Brussels. Analysis of Interviews with EU Correspondents and Spokespersons, Adequate Information Management in Europe (AIM) - Working Papers, 2007/3 (Bochum: Projekt Verlag, 2007).
} 
Briefly, the above discussion discloses one of the core contradictions in global and transnational communication, namely, between journalists' national belonging, on the one side, and the global topics they need to cover, on the other.

\section{THE INTERNET AND ITS POTENTIAL IN TRANSNATIONAL POLITICAL COMMUNICATION ${ }^{19}$}

In recent years there has been a growing interest in media and communication studies to redirect the attention from what is communicated in mainstream media and other official information offers (e.g., governmental web sites) to unofficial, non-governmental and social media projects attracting different groups of stake holders such as NGOs, political parties and candidates, governments, journalists and ordinary citizens. For example, different research studies reveal that in light of the problems of 'communicating Europe' there seems to be a yet unexplored potential of the Internet as means of (alternative, independent, analytical and transnational) information. Following this assumption, there is a need to redefine the role of new media technologies in the communication of issues having a global character.

With the emerging popularity and applicability of new interactive technologies a wide array of alternative online communication platforms have emerged offering all kinds of insights into global (European) matters. The new media applications range from those offering specialized information to ones accessed by general audiences. An important and distinctive feature of these platforms is their global and transnational orientation, which is especially useful for journalists in accessing background material and for other views on policy matters than those communicated by official sources in official documents. ${ }^{20}$ In addition, research studies also confirm that reporting on European politics increases in the European media with the advent of a younger generation of professional journalists, who rely on a clearer and more active understanding of the European dimension involved in their daily trade. ${ }^{21}$ Younger journalists are also the ones using the Internet as a primary source for background information, and searches for useful sources and critical views - these journalists have new media skills, they understand the European dimension; they also have a critical approach to issues communicated by officials and rely on new opportunities for investigative reporting. Another

19 Discussion here is based on the results obtained within the $6^{\text {th }} \mathrm{FP}$ project "Adequate Information Management in Europe (AIM)" conducted in the period of 2004-2007. Its aim was to disclose specific news production processes (EU information selection, analysis, editing, presentation) resulting in EU coverage in mass media in eleven European countries. Information about the project is available online at http://www.aim-project.net (accessed December 21, 2009).

${ }^{20}$ AIM Research Consortium, ed., supra note 18.

${ }^{21}$ Ibid. 
interesting observation is that journalists from newer member states of the EU, having less experience, knowledge and connections about how news is made in Brussels, use (institutional as well as informal, alternative) online channels to the same degree as their colleagues coming from Germany, France, U.K., etc. For example, since they are rather small groups of journalists from new EU member states, Lithuanians as well as Estonians do not have very close informal relations with the spokespersons of the European Commission, nor are they in very close cooperation with other foreign colleagues. ${ }^{22}$ Despite the fact that informal relations can be very useful for their work, they receive information mainly via formal channels, which also include different Internet sources (blogs, online media, social networks), press releases, midday briefings and press conferences. One problem, however, is that the editors in their home offices also have access to most Internet sources at home and demand more grounded justifications for the correspondents' presence in Brussels. In spite of considerations that amateur reporting offers valuable perspectives on news (which is often missed by the traditional media), there are justified concerns that Internet news, especially when provided by do-ityourself journalists and citizens, can lead to error, rumor and propaganda.

As mentioned, the political and institutional actors understand the growing importance and usability of new media technologies and attribute a substantial role of their communication activities to the Internet. Some media, too, have increased their investment in the development of new media journalism initiatives (ranging from institutionalized media projects such as EurActive, EuroZine, EU Observer, Café Babel and so forth, to less organized initiatives facilitated through social media, for e.g., Facebook, Twitter, MySpace, etc.) which give insights into event development, provide quick news and background facts needed for analysis, and offer transnational and alternative views on (European) everyday matters and policies. Searching for inspiration, alternative sources and views, journalists eagerly turn to non-official online sources, web sites of different NGO's and interest groups, weblogs, and online communities and forums. Here journalists are able to find out what is being discussed by different society groups and get a feel of news development.

In conclusion, taking into the account the EU's communication problems - the bureaucratic jargon, the overflow of official information, the lack of transparency, the pitfalls of cross-cultural misunderstandings, etc. - independent online news

\footnotetext{
${ }^{22}$ Auksė Balčytienè, Aušra Vinciūnienè, and Kristina Janušaitė, "The Case of Lithuania"; in: AIM Research Consortium, ed., Understanding the Logic of EU Reporting from Brussels. Analysis of Interviews with EU Correspondents and Spokespersons, Adequate Information Management in Europe (AIM) - Working Papers, 2007/3 (Bochum/Freiburg: Projekt Verlag, 2007); Pia Tammpuu and Evelin Pullerits, "The Case of Estonia"; in: AIM Research Consortium, ed., Understanding the Logic of EU Reporting from Brussels. Analysis of Interviews with EU Correspondents and Spokespersons, Adequate Information Management in Europe (AIM) - Working Papers, 2007/3 (Bochum/Freiburg: Projekt Verlag, 2007).
} 
sources (citizen blogs, alternative media, social networks) have become of crucial importance for different actors (journalists as well as ordinary citizens) to gain insights and fresh knowledge about EU policy-making processes.

\section{CONCLUSIONS AND DISCUSSION}

The emergence of a knowledge-based society obviously changes the role and functions of new media as well as its applications by journalists, political actors and citizens. On the whole, it is still an open question whether new media applications, although offering collective platforms for different interests to meet and communicate, will have as much impact on public knowledge, opinion and (non)participation in public matters as any other traditional media. More research is needed to determine whether a limitless online public sphere leads to the increase of public engagement and participation, to the emergence of transnational communicative spaces, or if it merely deactivates the political potential of citizens.

At the same time, the available research proves that new media is widely used by the younger generation of journalists, politicians and audiences who possess adequate new media skills, and are critical and understand the importance of the global dimension in communication. As the discussion here has demonstrated, for journalists the availability of alternative information on the Internet offers rich information, transnational perspectives; thus, these online resources might offer new means to recognize common interests of different citizens and present news in a more global framework rather than predominantly national and local. With the advent of new technological means and their applications in communication, the role and function of professional journalists will also change: instead of being only gate-keepers and agenda-setters they will become interpreters, critics and evaluators.

Generally, two visions can be drawn from this discussion on how changes in technologies will affect the nature of transnational political communication. One of them sees structural changes such as changes in institutional conditions of political and media systems and relies strongly on the universalizing character of new media technologies and their potential to engage different fragmented audiences in debates and deliberation on issues of a global character. The other vision still strongly relies on contextual factors and relates to the particularities of communication histories and traditions of national context and national communication culture, and their impact on working routines and messages communicated. Indeed, although contradicting, the two emerging tendencies of 
globalization and localism can be interpreted as an opportunity to critically reassess and revisit old questions in political communication research.

\section{BIBLIOGRAPHY}

1. Adam, Silke. "Domestic Adaptations of Europe: A Comparative Study of the Debates on EU Enlargement and a Common Constitution in the German and French Quality Press." International Journal of Public Opinion Research Vol. 19, No. 4 (2007): 409-433.

2. AIM Research Consortium, ed. Understanding the Logic of EU Reporting from Brussels. Analysis of Interviews with EU Correspondents and Spokespersons. Adequate Information Management in Europe (AIM) - Working Papers, 2007/3. Bochum/Freiburg: Projekt Verlag, 2007.

3. Baisnée, Olivier. "Can political journalism exist on EU level?": 108-128. In: R. Kuhn and E. Neveu, eds. Political Journalism: New Challenges, New Practices. London/New York: Routledge, 2002.

4. Balčytienè, Auksè, and Aušra Vinciūnienè. "Political communication culture with a European touch: a view from Brussels." Sociologija: mintis ir veiksmas 3 (2008): 71-86.

5. Balčytienè, Auksè, Aušra Vinciūnienè, and Kristina Janušaitè. "The Case of Lithuania": 103-110. In: AIM Research Consortium, ed., Understanding the Logic of EU Reporting from Brussels. Analysis of Interviews with EU Correspondents and Spokespersons, Adequate Information Management in Europe (AIM) - Working Papers, 2007/3. Bochum/Freiburg: Projekt Verlag, 2007.

6. Brüggemann, Michael, and Katharina Kleinen-von Königslöw. "Let's talk about Europe. Why Europeanization Shows a Different Face in Different Newspapers." European Journal of Communication, Vol. 24, No. 1 (2009): 2748.

7. Castells, Manuel. "The New Public Sphere: Global Civil Society, Communication Networks, and Global Governance." American Academy of Political \& Social Science Annals Vol. 616, No. 3 (2008): 78-93.

8. Coleman, Renita, Paul Lieber, Andew L. Mendelson, and David D. Kurpius. "Public Life and the Internet: If You Build a Better Website, Will Citizens Become Engaged?" New Media \& Society 10 (2008): 179-201.

9. Coleman, Stephen. "New Mediation and Direct Representation: Reconceptualizing Representation in the Digital Age." New Media and Society Vol. 7, No. 2 (2005): 177-198. 
10. Corburn, Jason. Street Science: Community Knowledge and Environmental Health Justine. Cambridge: The MIT Press, 2005.

11. Dahlgren, Peter. "Internet, Public Spheres and Political Communication: Dispersion and Deliberation." Political Communication Vol. 22, No. 2 (2005): 147-162.

12. Dahlgren, Peter. "Doing Citizenship: The Cultural Origins of Civic Agency in the Public Sphere." European Journal of Cultural Studies 9 (2006): 267-286.

13. Davis, Aeron. "New Media and Fat Democracy: the Paradox of Online Participation." New Media and Society Vol. 11, No. 8 (2009): 1-20.

14. Dutton, William H. "The Fifth Estate: Democratic Social Accountability through the Emerging Network of Networks." June 10, 2008 //

http://papers.ssrn.com/sol3/papers.cfm?abstract_id=1167502 (accessed December 21, 2009).

15. Eriksen, Erik Oddvar. "An Emerging European Public Sphere." European Journal of Social Theory Vol. 8, No. 3 (2005): 341-363.

16. Esser, Frank, and Barbara Pfetsch. Comparing Political Communication. Theories, Cases and Challenges. Cambridge: Cambridge University Press, 2004.

17. Gavin, Neil T. "British Journalists in the Spotlight: Europe and Media Research." Journalism Vol. 2, No. 3 (2001): 299-314.

18. Gurevitz, Michael, Stephen Coleman, and Jay G. Blumler. "Political Communication - Old and New Media Relationships." The ANNALS of the American Academy of Political and Social Science 625 (September 2009): 164-181.

19. Hallin, Daniel, and Paolo Mancini. Comparing Media Systems. Three Models of Media and Politics. Cambridge: Cambridge University Press, 2004.

20. Heikkila, Heikki, and Risto Kunelius. "Journalists imagining the European Public Sphere." Javnost: The Public Vol. 4, No. 4 (2007): 63-80.

21. Koopmans, Ruud. "Who inhabits the European public sphere? Winners and losers, supporters and opponents in Europeanised public debates." European Journal of Political Research Vol. 46, No. 2 (2007): 183-210.

22. Lecheler, Sophie. "EU Membership and the Press: An Analysis of the Brussels Correspondents from the New Member States." Journalism Vol. 9, No. 4 (2008): 443-464.

23. Machill, Marcel, Marcus Beiler, and Corinna Fischer. "Europe-topics in Europe's Media. The Debate about the European Public Sphere: A Meta-Analysis of Media Content Analyses." European Journal of Communication Vol. 21, No. 1 (2006): 57-88. 
24. Mancini, Paolo. "Journalism Cultures: A Multi-level Proposal": 149-168. In: O. Hahn \& R. Schroeder, eds. Journalistische Kulturen: Internationale und interdisziplinare Theoriesbausteine. Koln: Herbert von Halem Verlag, 2008.

25. Meyer, Christoph O. "The Europeanization of Media Discourse: A Study of Quality Press Coverage of Economic Policy Co-ordination since Amsterdam." Journal of Common Market Studies Vol. 43, Issue 1 (2005): 121-148.

26. Morgan, David. "British Media and European Union News: The Brussels News Beat and its Problems." European Journal of Communication Vol. 10, No. 3 (1995): 321-343.

27. Newman, Nic. "The Rise of Social Media and Its Impact on Mainstream Journalism: A study of how newspapers and broadcasters in the UK and US are responding to a wave of participatory social media, and a historic shift in control towards individual consumers. Working Paper." September 2009 // http://go2. wordpress.com/?id=725X1342\&site=reinventingthenewsroom . wor dpress.com\&url=http $\% 3 \mathrm{~A} \% 2 \mathrm{~F} \% 2$ Freutersinstitute. politics.ox.ac.uk\%2Ffilead min\%2Fdocuments\%2FPublications\%2FThe_rise_of_social_media_and_its_im pact_on_mainstream_journalism.pdf (accessed December 21, 2009).

28. Olausson, Ulrika. "Global Warming global responsibility? Media frames of collective action and scientific certainty." Public Understanding of Science 18 (2009): 421-436.

29. Pfetsch, Barbara, Silke Adam, and Barbara Eschner. "The Contribution of the Press to Europeanization of Public Debates: A Comparative Study of Issue Salience and Conflict Lines of European Integration." Journalism Vol. 9, No. 4 (2008): 465-492.

30. Semetko, Holli A., Claes de Vreese, and Jochen Peter. "Europeanised Politics Europeanised Media? European Integration and Political Communication." West European Politics Vol 23, No. 4 (2000): 121-141.

31. Statham, Paul. "Making Europe News: How Journalists View Their Role and Media Performance." Journalism Vol. 9, No. 4 (2008): 399-421.

32. Tammpuu, Pia, and Evelin Pullerits. "The Case of Estonia": 15-22. In: AIM Research Consortium, ed., Understanding the Logic of EU Reporting from Brussels. Analysis of Interviews with EU Correspondents and Spokespersons. Adequate Information Management in Europe (AIM) - Working Papers, 2007/3. Bochum/Freiburg: Projekt Verlag, 2007.

33. Tjernström, Vanni. "Nordic Newspapers on the EU: European Political Journalism after 'Non' and 'Nee'." Journalism Vol. 9, No. 4 (2008): 516-536. 
34. Trenz, Hans-Jörg. "Media Coverage on European Governance: Exploring the European Public Sphere in National Quality Newspapers." European Journal of Communication Vol. 19, No. 3 (2004): 291-319. 